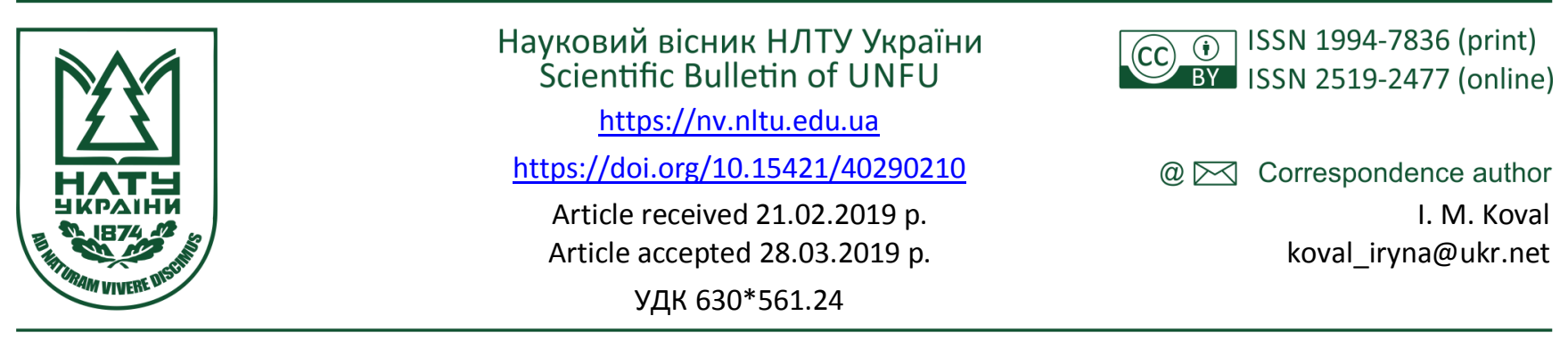

І. М. Коваль 1 В. Л. Борисова ${ }^{2}$

${ }^{I}$ Український НДІ лісового господарства і агромеліораиії ім. Г. М. Висоиького, м. Харків, Украӥна

${ }^{2}$ Харківський начіональний аграрний університет ім. В. В. Докучаєва, м. Харків, Україна

\title{
РЕАКЦІЯ НА ЗМІНИ КЛІМАТУ РАДІАЛЬНОГО ПРИРОСТУ ЯСЕНА ЗВИЧАЙНОГО В НАСАДЖЕННЯХ ЛІВОБЕРЕЖНОГО ЛІСОСТЕПУ
}

Дендрохронологічними методами досліджено динаміку товщини шарів ранньої, пізньої та річної деревини Fraxinus ex-
celsior L. і реакцію радіального приросту на зміни клімату у вологому субору Лівобережного Лісостепу. Встановлено роки
мінімального приросту (1975, 1987, 1999, 2000, 2012), зумовленого посухами, холодними та теплими зимами й аномальними
ранньовесняними температурами. Роки максимального приросту (1973, 1980, 1996 та 2004) характеризуються сприятливим
співвідношенням тепла та вологи. Встановлено кореляційні залежності між товщиною шарів ранньої, пізньої та річної дере-
вини і кліматичними чинниками. Внаслідок посушливої погоди 1999-2000 рр. відбулося зрідження насадження, що спричи-
нило значну диференціацію дерев різних категорій санітарного стану за величинами шарів річної деревини. Відхилення від
норми температури та опадів на 30 \% та більше як у більшу, так і в меншу сторону, спричиняє депресію радіального при-
росту ясена. Упродовж 1975-1995 рр. радіальний приріст ясена обмежували високі температури вегетаційного періоду, а у
наступні 1995-2016 рр. - березневі, квітневі та зимові температури. Встановлено, що опади вересня та грудня попереднього
року позитивно вплинули на приріст у 1975-1995 рр. Для 1996-2016 рр. визначено зворотний зв'язок між річним радіальним
приростом і липневими опадами. Кількість істотних зв'язків між кліматичними показниками і радіальним приростом не
збільшилася у другому періоді, що свідчить про стабільний стан лісостану.
Ключові слова: Fraxinus ехсеlsior L.; рання деревина, пізня деревина; річна деревина; дендрохронологічні методи; кліматичні чинники.

Вступ. Середня температура в Україні за останні десять років підвищилася на $0,3-0,6^{\circ} \mathrm{C}$ (за останні 100 років - на $0,7^{\circ} \mathrm{C}$ ) (Didukh, 2009). Зміни клімату впливають на стійкість лісів (Krakovska et al., 2017), тобто збереження ними здатності реагувати на мінливість кліматичних чинників. Радіальний приріст є інтегральним показником, який відображає вплив довкілля на стан дерева (Cook, 1990). Втрата стійкості лісів у разі нестабільної екологічної ситуації може виявлятися в мінливості радіального приросту дерев та його постійному пригніченні (Ray et al., 2010).

Серед насаджень лісотвірних порід України важливе місце посідають лісостани ясена звичайного (Fraxinus excelsior L.). Насадження ясена на території України займають площу близько $6 \%$ (151,6 тис. га) від усіх листяних лісів (Gulchak, 2012). У багатьох роботах розглянуто ясеневі насадження в Україні, досліджено їхні лісівничі властивості, способи лісовідновлення, поліпшення стану та підвищення продуктивності цих деревостанів (Pogrebnjak, 1955; Gordienko, 2005, Davydenko et al., 2013; Goychuk, 2014; Matsiakh \& Kramarets, 2014; Kowalski et al., 2015; Davydenko \& Meshkova, 2017; Langer, 2017; Meshkova \& Borysova, 2017).

Більшість досліджень ясеневих насаджень присвячена Правобережному Лісостепу (Lavnyy, 2000; Lakyda,
2011; Matsiakh \& Kramarets, 2014). Вивчаючи вплив зміни клімату на радіальний приріст ясена в Лісостеповій частині Правобережної України, виявлено погіршення стану насаджень за останні десятиріччя (Koval et al., 2015). Реакцію радіального приросту ясена звичайного в насадженнях Лівобережного Степу недостатньо вивчено, і це дослідження дає змогу покращити розуміння, як кліматичні зміни можуть вплинути на стан ясенових насаджень.

Мета дослідження - вивчити реакцію радіального приросту ясена звичайного (Fraxinus excelsior L.) на зміни клімату в умовах вологого субору.

Матеріал і методи дослідження. Дослідження проведено у Мохначанському лісництві ДП "Скрипаївське ННЛГ" (кв. 10, вид. 4). Тип лісорослинних умов $-\mathrm{C}_{3}$, тип лісу $-\mathrm{C}_{3}$ КЛД, вік ясена - 60 років. Склад 4Дз3Яз2Лпд1Клг. Походження насадження - паросткове вегетативне. $H_{c e p .}-20$ м; $D_{c e p .}-24,6$ см. Клімат помірно континентальний. За даними Харківської метеостанції, найтеплішим $\left(21,0{ }^{\circ} \mathrm{C}\right)$ і найвологішим (72 мм) місяцем є липень, а найхолоднішим - січень $\left(-5,5^{\circ} \mathrm{C}\right)$; найменшою кількістю опадів характеризується березень (33,5 мм). Середньорічна температура становить $8,1^{\circ} \mathrm{C}$.

Використано таксаційні, дендрохронологічні та статистичні методи. Керни відібрано буравом Преслера у

\section{Інформація про авторів:}

Коваль Ірина Михайлівна, канд. с.-г. наук, пров. наук. співробітник, лабораторія екології лісу. Email: koval_iryna@ukr.net Борисова Валентина Леонідівна, студент, кафедра лісівництва ім. Б. Ф. Остапенка. Email: borisova.valentina@ukr.net Цитування за ДСтУ: Коваль І. М., Борисова В. Л. Реакція на зміни клімату радіального приросту ясена звичайного в насадженнях Лівобережного Лісостепу. Науковий вісник НЛтУ України. 2019, т. 29, № 2. С. 53-57.

Citation APA: Koval, I. M., \& Borysova, V. L. (2019). Ash radial growth response to climate change in the stands of Left Bank ForestSteppe. Scientific Bulletin of UNFU, 29(2), 53-57. https://doi.org/10.15421/40290210 
15 дерев ясена звичайного в біогрупі на висоті 1,3 м від рівня землі. Керни висушили на повітрі й виміряли шари ранньої та пізньої деревини приладом HENSON 3 точністю до 0,01 мм. Перехресним датуванням встановили рік утворення кожного шару деревини, а потім якість вибірки перевірили програмою COFECHA (Cook, 1990).

Індекси деревно-кільцевих хронологій річної, ранньої та пізньої деревини обчислили методом 3-річної ковзної (Cook, 1990). Проведено кореляційний аналіз зв'язків між індексними деревно-кільцевими хронологіями та метеорологічними показниками (температурою повітря та кількістю опадів) для двох періодів - 19751995 та 1996-2016 рр., щоб оцінити вплив змін клімату на радіальний приріст усіх видів деревини.

Коефіцієнт чутливості - це відносна величина міжрічної мінливості приросту в серіях річних кілець індивідуальних хронологій, який обчислюють шляхом знаходження абсолютної різниці сусідніх значень ширини кілець, поділеної на їх середнє значення за формулою

$$
K=\frac{1}{n-1} \sum_{t=1}^{n-1} \frac{2\left(x_{t+1}-x_{t}\right)}{x_{t+1}+x_{t}},
$$

де: $x_{t}$ - ширина річного кільця, або індекс приросту за рік $t ; n$-кількість років.

Чим вищим є значення коефіцієнта, тим сильнішим $\epsilon$ кліматичний сигнал у деревно-кільцевих хронологіях. Серію кілець вважають чутливою, коли середній коефіцієнт чутливості перевищує 0,3 (Cook, 1990).

Результати дослідження та їх обговорення. Найбільш синхронними виявилися деревно-кільцеві хронології річної деревини, а найменш подібними - деревно-кільцеві хронології ранньої деревини, про що свідчить множинний коефіцієнт кореляції між деревнокільцевими хронологіями кожного дерева. Коефіцієнти автокореляції, які відображають вплив радіального приросту попереднього року на радіальний приріст поточного року, є високими для всіх видів деревини. Найменш чутливою до змін умов довкілля виявилася рання деревина, а найбільш чутливою - пізня (табл. 1).

Табл. 1. Статистичні показники деревно-кільцевих хронологій річної, пізньої та ранньої деревини ясена звичайного

\begin{tabular}{|c|c|c|c|c|c|c|}
\hline Вид деревини & Період, роки & $\begin{array}{c}\text { Множинний коефіцієнт ко- } \\
\text { реляції для дерев деревно- } \\
\text { кільцевої хронології }\end{array}$ & $\begin{array}{c}\text { Середнє зна- } \\
\text { чення прирос- } \\
\text { ту, мм }\end{array}$ & $\begin{array}{c}\text { Стандартне } \\
\text { відхилення }\end{array}$ & $\begin{array}{c}\text { Коеффіцієнт ав- } \\
\text { токореляції }\end{array}$ & $\begin{array}{c}\text { Середня чусть деревно-кіль- } \\
\text { цевих хронологій }\end{array}$ \\
\hline Річна & $1970-2017$ & 0,419 & 2,47 & 1,197 & 0,661 & 0,226 \\
\hline Пізня & $1970-2017$ & 0,383 & 1,66 & 1,015 & 0,634 & 0,323 \\
\hline Рання & $1970-2017$ & 0,100 & 0,82 & 0,425 & 0,402 & 0,251 \\
\hline
\end{tabular}

Визначено роки мінімального приросту: 1975, 1987, 1999, 2000 та 2012, зумовлені несприятливими погодними умовами (рис. 1-3).

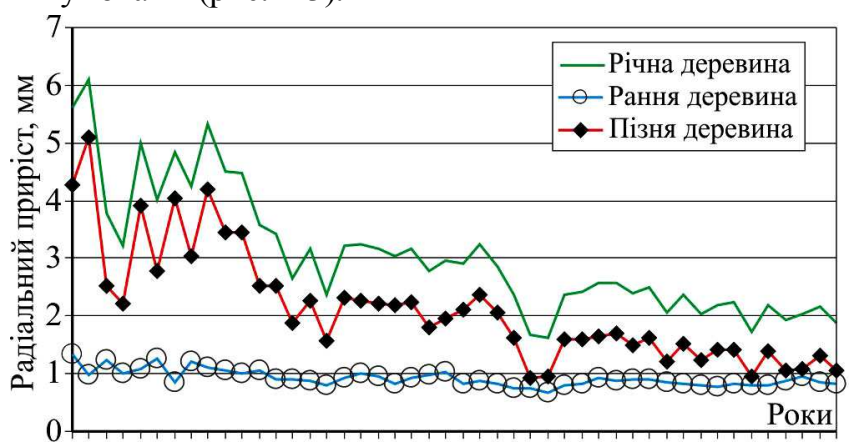

197219761980198419881992199620002004200820122016 Рис. 1. Динаміка радіального приросту ранньої, пізньої та річної деревини ясена звичайного у вологому сугруді $\left(\mathrm{C}_{3}\right)$

За норму взято середні температури та опади за 1960-2017 рр. Мінімальний радіальний приріст 1975 р. зумовлений дефіцитом вологи впродовж вегетаційного періоду (відхилення від середньої суми опадів за квітень - серпень становило 40 \%). У 1987 р. приріст обмежували низькі зимові температури, які на 30 \% поступалися нормі, та липневі опади, які були на $68 \%$ нижчі від норми. Можливо, що внаслідок дії низьких зимових температур відбулося обмерзання крон, особливо однорічних пагонів. Доволі часто виявлено морозобійні тріщини на стовбурах, що негативно впливає на життєдіяльність пошкоджених дерев і на формування річних кілець (Lavnyy, 2000). У 1999 р. радіальний приріст обмежували підвищені зимові та ранньовесняні температури (відхилення від норми - 42 та 77 \% відповідно). У 1999 р. радіальний приріст обмежували підвищені зимові та ранньовесняні температури (відхилення від норми сягали 42 та 77 \% відповідно) (див. рис. 1-3). Можливо, часті відлиги взимку та високі температури в березні сприяли високому рівню грунтових вод навесні.
Відомо, що внаслідок тривалого підтоплення відбувається відмирання коренів та знижується гідравлічна провідність ранньої деревини в затопленому стовбурі, що зумовлює зменшення радіального приросту дерев (Copini et al., 2016).

У насадженнях Правобережного Лісостепу виявлено негативний вплив високих зимових і весняних температур на радіальний приріст ясена (Koval et al., 2015). У 2012 р. приріст обмежували липневі опади, яких випало на $72 \%$ менше від норми. Тобто, якщо відхилення від норми температури та опадів за різні періоди вегетаційного та календарного років сягали 30 \% і більше, то виникала велика ймовірність депресії радіального приросту ясена. Максимальні величини радіального приросту 1973, 1980, 199 та 2004 рр. зумовлені сприятливим співвідношенням тепла та вологи (див. рис. 1-3).

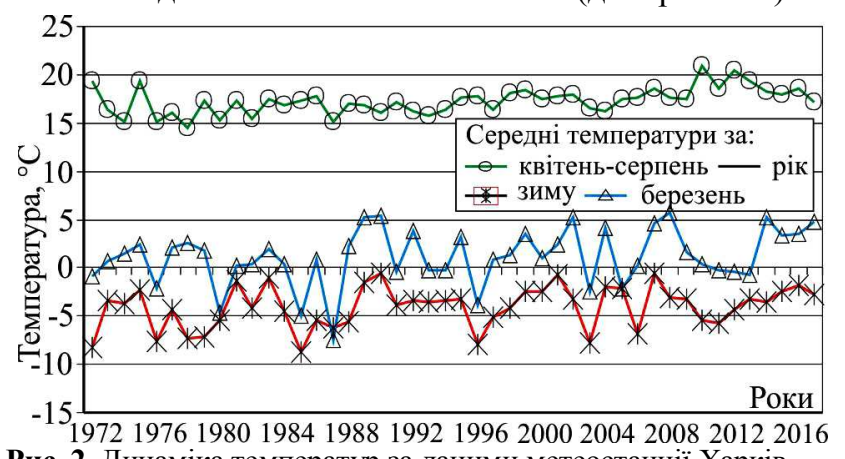

Рис. 2. Динаміка температур за даними метеостанції Харків

За результатами аналізу радіального приросту дерев ясена різного санітарного стану не виявлено відмінностей у 1981-1989 pр. Пізніше, внаслідок посушливого липня 1990 р., коли опадів випало на 42 \% менше від норми, відбувся відпад дерев. Внаслідок збільшення площі живлення дерев радіальний приріст ясена звичайного 1-ї категорії санітарного стану різко збільшився Після двох поспіль посушливих років (1999 та 2000 рр.) відбулися всихання ослаблених дерев і по- 
дальша диференціація радіального приросту дерев, які залишилися (рис. 4).

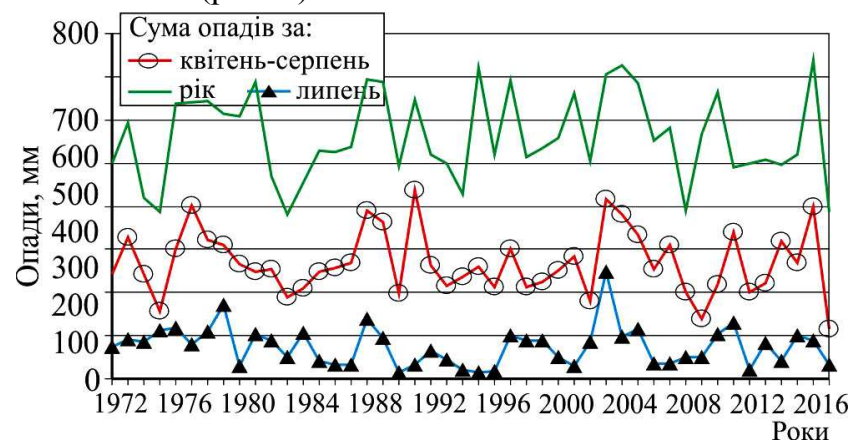

Рис. 3. Динаміка сум опадів за даними Харківської метеостанції

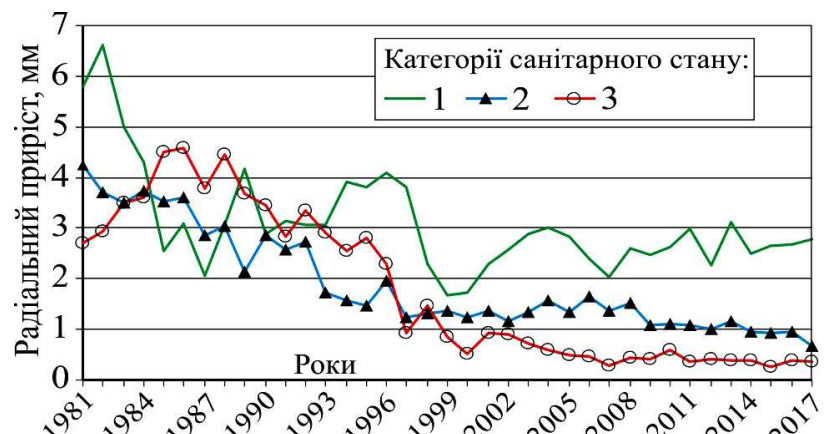

Рис. 4. Динаміка радіального приросту дерев ясена звичайного різних категорій санітарного стану у вологому сугруді $\left(\mathrm{C}_{3}\right)$

Упродовж 1984-2000 pр. різниця між радіальним приростом дерев 1-ї та 2-ї категорій санітарного стану становила 26\%, а дерев 1-ї та 3-ї категорій - 8\%. У наступні 2001-2017 рр. ця різниця збільшилася до 55 та $81 \%$ відповідно. У 1981-2000 рр. виявлено значущу різницю між радіальним приростом дерев 1-ї та 2-ї категорій. Унаслідок подальшої диференціації між деревами у другому періоді (1996-2016 рр.) зафіксовано значущу різницю між середніми значеннями величин річних кілець дерев різних категорій санітарного стану (табл. 2).

Табл. 2. Статистична характеристика дерев різних категорій санітарного стану за 1981-2000 та 2001-2017 pp.

\begin{tabular}{|c|c|c|c|c|}
\hline \multirow{2}{*}{$\begin{array}{l}\text { Категорія } \\
\text { санітарного } \\
\text { стану дерев }\end{array}$} & \multirow{2}{*}{$\begin{array}{c}\text { Радіальний } \\
\text { приріст, мм, } \\
X \pm S x\end{array}$} & \multirow[b]{2}{*}{ Дисперсія } & \multicolumn{2}{|c|}{ Достовірність ** } \\
\hline & & & $t_{\text {факт. }}$ & $t_{\text {meop. }}$ \\
\hline \multicolumn{5}{|c|}{ 1984-2000 pp. } \\
\hline 1 & $3,10^{ \pm 0,20}$ & 0,71 & - & - \\
\hline 2 & $2,29^{ \pm 0,21}$ & 0,78 & $2,73_{0,01}$ & 2,68 \\
\hline 3 & $2,86^{ \pm 0,31}$ & 1,65 & 0,64 & 2,04 \\
\hline \multicolumn{5}{|c|}{ 2001-2017 pp. } \\
\hline 1 & $2,63^{ \pm 0,07}$ & 0,08 & - & - \\
\hline 2 & $1,19^{ \pm 0,06}$ & 0,07 & $15,23_{0,001}$ & 3,65 \\
\hline 3 & $0,49^{ \pm 0,05}$ & 0,04 & $25,92_{0,001}$ & 3,65 \\
\hline
\end{tabular}

Примітка: $0,01-$ рівень значущості; ** - достовірність різниці між середніми значеннями радіального приросту дерев 1-ї категорії санітарного стану і 2-ї та 3-ї категорій

Для першого періоду (1975-1995 рр.) визначено додатні коефіцієнти кореляції між температурою та приростом річної й пізньої деревини попереднього року. Також виявлено, що високі температури вегетаційного періоду (травневі, червневі та середні за квітень - серпень) обмежували формування річної та ранньої деревини ясена (табл. 3).

У другому періоді (1996-2016 рр.) значне збільшення температури рано навесні негативно вплинуло на річний радіальний приріст. Підвищення квітневих і зимових температур істотно обмежило формування шарів ранньої деревини. Під час тривалого затоплення водою камбій дерев пошкоджується у прикореневій частині стовбура (Lavnyy, 2000), що може негативно впливати на приріст.

Табл. 3. Кореляційний аналіз зв'язків між індексами радіального приросту річної, ранньої та пізньої деревини ясена та температурою за 1975-1995 та 1996-2016 pp.

\begin{tabular}{|c|c|c|c|c|c|c|}
\hline \multirow[b]{2}{*}{ Місяць } & \multicolumn{2}{|c|}{ Річна деревина } & \multicolumn{2}{|c|}{ Пізня деревина } & \multicolumn{2}{|c|}{ Рання деревина } \\
\hline & $\begin{array}{c}1975- \\
1995\end{array}$ & $\begin{array}{l}1996- \\
2016\end{array}$ & $\begin{array}{l}1975- \\
1995\end{array}$ & $\begin{array}{l}1996- \\
2016\end{array}$ & $\begin{array}{c}1975- \\
1995\end{array}$ & $\begin{array}{l}1996- \\
2016\end{array}$ \\
\hline $\mathrm{VI}_{(-1)}$ & $0,59 *$ & - & $0,56^{*}$ & - & - & - \\
\hline $\mathrm{VII}_{(-1)}$ & + & + & + & - & - & - \\
\hline $\mathrm{VIII}_{(-1)}$ & + & + & + & + & - & + \\
\hline $\mathrm{IX}_{(-1)}$ & + & - & + & + & - & + \\
\hline $\mathrm{X}_{(-1)}$ & - & + & - & - & - & - \\
\hline $\mathrm{XI}_{(-1)}$ & - & - & - & + & - & + \\
\hline $\mathrm{XII}_{(-1)}$ & + & + & - & - & + & - \\
\hline I & - & + & - & - & + & - \\
\hline II & - & + & - & - & + & - \\
\hline III & + & $-0,44^{*}$ & + & - & + & - \\
\hline IV & + & + & + & - & + & $-0,42 *$ \\
\hline $\mathrm{V}$ & $-0,66^{*}$ & + & $-0,69^{*}$ & + & + & + \\
\hline VI & $-0,45^{*}$ & - & $-0,42 *$ & - & + & - \\
\hline VII & - & - & - & - & + & + \\
\hline VIII & - & - & - & 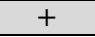 & + & - \\
\hline $\mathrm{XII}_{(-1)}, \mathrm{I}, \mathrm{II}$ & - & - & - & - & + & $-0,41 *$ \\
\hline IV-VIII & $-0,48 *$ & - & $-0,49 *$ & - & + & - \\
\hline 111 & & - & & - & + & - \\
\hline
\end{tabular}

Примітки: -1 - місяці попереднього року; + - додатні зв'язки; - - від'ємні зв'язки; ${ }^{*}-$ значущість на рівні 0,05 .

Подібну реакцію приросту річної та пізньої деревини на коливання температури, особливо у перший період, можна пояснити переважанням пізньої деревини в річному кільці, частка якої становить у дослідженому насадженні 52-84 \%. Подібні результати отримали дослідники, які вивчали взаємозв'язки між кліматом і радіальним приростом ясеня американського (Fraxinus americana) й визначили однакові коефіцієнти кореляції як для річного кільця, так і для пізнього шару деревини, який на 98 \% пояснює варіабельність ширини усього річного кільця в ясенах (Lockwood \& LeBlanc, 2017).

Табл. 4. Кореляційний аналіз зв'язку між індексами радіального приросту річної, ранньої та пізньої деревини ясена та опадами за 1975-1995 та 1996-2016 pp.

\begin{tabular}{|c|c|c|c|c|c|c|}
\hline \multirow{2}{*}{ Місяць } & \multicolumn{2}{|c|}{ Річна деревина } & \multicolumn{2}{c|}{ Пізня деревина } & \multicolumn{2}{|c|}{ Рання деревина } \\
\cline { 2 - 8 } & $1975-$ & $1996-$ & $1975-$ & $1996-$ & $1975-$ & $1996-$ \\
& 1995 & 2016 & 1995 & 2016 & 1995 & 2016 \\
\hline VI $_{(-1)}$ & - & + & - & - & + & + \\
\hline VII $_{(-1)}$ & + & - & + & - & + & - \\
\hline VIII $_{(-1)}$ & + & + & + & + & - & + \\
\hline IX $_{(-1)}$ & - & + & - & + & $0,56^{*}$ & + \\
\hline X $_{(-1)}$ & - & + & - & + & - & - \\
\hline XI $_{(-1)}$ & + & + & + & + & - & - \\
\hline XII $_{(-1)}$ & - & + & - & + & $0,53^{*}$ & - \\
\hline I & + & - & + & + & + & - \\
\hline II & - & + & - & - & + & + \\
\hline III & - & - & - & - & - & - \\
\hline IV & + & + & + & + & + & + \\
\hline V & + & - & + & + & - & - \\
\hline VI & + & + & + & + & - & + \\
\hline VII & + & $-0,41^{*}$ & + & + & + & + \\
\hline VIII & - & - & - & - & + & - \\
\hline XII (-1), I, II & - & + & - & + & + & - \\
\hline IV-VIII $^{2}$ & + & + & + & + & + & + \\
\hline I-XII & + & + & + & + & - & - \\
\hline
\end{tabular}

Примітки: -1 - місяці попереднього року; + - додатні зв'язки; - - від'ємні зв'язки; ${ }^{*}-$ значущість на рівні 0,05 .

Додатні коефіцієнти кореляції між опадами та приростом ранньої деревини визначено лише для вересня та грудня попереднього року для першого періоду, що 
може бути пов'язано зі сприятливими умовами для підготовки дерев до зимового спокою та вологонакопичення (табл. 4). У другому періоді обчислено зворотні зв'язки між радіальним приростом і опадами за липень. Це можна пояснити тим, що одночасно зі збільшенням кількості опадів на $10 \%$ температура зросла на $7 \%$, що сприяло випаровуванню, тобто відбулося зменшення кількості доступної вологи для життєдіяльності дерев (див. табл. 3). Дослідники стверджують (Ray et al., 2010; Lockwood at al., 2017), що вплив клімату на стан ясена ясен залежить від співвідношення зміни температури та опадів, що впливає на інтенсивність посух упродовж вегетаційного періоду.

Висновки. Середня температура повітря у 19751995 pp. є більшою порівняно з періодом 1996-2017 pр.: за зиму на $15 \%$, за квітень - серпень - на $9 \%$, за березень - майже вдвічі, за рік - на $16 \%$. Період 19962017 рр., порівняно $з$ 1975-1995 рр., характеризується зменшенням кількості середньорічних опадів (1\%) за квітень - серпень (на 5 \%) і збільшенням зимових опадів (на $2 \%$ ). Відхилення від норми температури та опадів на 30 \% та більше як у більшу, так і в меншу сторону, спричиняє депресію радіального приросту ясена. 2012 рр. зумовлений посухами, високими та низькими температурами протягом ранньої весни та зими, а максимальний приріст 1973, 1980, 1996 та 2004 рр. визначено за сприятливого співвідношення тепла та вологи. Унаслідок посушливої погоди 1999-2000 рр. відбулося зрідження насадження, що спричинило значну диференціацію дерев різних категорій санітарного стану за величинами шарів річної деревини.

Упродовж 1975-1995 рр. радіальний приріст ясена обмежували температури вегетаційного періоду, а у наступні 1995-2016 pp. - березневі, квітневі та зимові температури. Опади вересня та грудня попереднього року позитивно вплинули на приріст у 1975-1995 рр., а у 1996-2016 рр. виявлено негативний вплив липневих опадів на формування річного кільця ясеня.

Кількість істотних зв'язків між кліматичними показниками і радіальним приростом не збільшилася у другому періоді, що свідчить про стабільний стан лісостану.

\section{Перелік використаних джерел}

Cook, E. R., \& Kairiukstis, L. (1990). Methods of Dendrochronology - Applications in the Environmental Sciences. Dordrecht, Netherlands: Kluwer Academic Publishers and International Institute for Applied Systems Analysis.

Copini, P., Ouden, J., Robert, E., Tardif, J., Loesberg, W., Goudzwaard, L., \& Sass-Klaassen, U. (2016). Flood-Ring Formation and Ro-
Мінімальний приріст ясена у 1975, 1987, 1999, 2000,

ot Development in Response to Experimental Flooding of Young Quercus robur Trees. Frontiers Plant Science, 7-75.

Davydenko, K., \& Meshkova, V. (2017). The current situation concerning severity and causes of ash dieback in Ukraine caused by Hymenoscyphus fraxineus. Dieback of European Ash (Fraxinus spp.), 220-227.

Davydenko, K., Vasaitis, R., Stenlid, J., \& Menkis, A. (2013). Fungi in foliage and shoots of Fraxinus excelsior in eastern Ukraine: a first report on Hymenoscyphus pseudoalbidus. Forest Pathology, 43(6), 462-467.

Didukh, Ya. (2009). Ecological aspects of global climate change: the reasons, consequences and actions. Visnyk of the National Academy of Sciences of Ukraine, 2, 34 44. [In Ukrainian].

Goychuk, A., \& Kulbanska, I. (2014). Etymology of common Ash diseases in Podolia, Ukraine. (Ser. Forestry and ornamental plants). Scientific Journal of NUBiP of Ukraine, 198. [In Ukrainian].

Gulchak, V. P. (2012). State forest register of Ukraine - results and forecasts. Lisovyi i myslyvskyi zhurnal, 2, 6-8. [In Ukrainian].

Hordiyenko, M. I. (2005). Forestry properties of wood plants. Kyiv: TOV "Vistka", 817 p. [In Ukrainian].

Koval, I. M., Bolohov, O. V., Nusbaum, S. A., \& Yuzvonskyy, H. A. (2015). Radial growth of English oak and European ash as an indicator of forest ecosystem condition in the conditions of NovogradVolyn physical \& geographical region. Lisivnytstvo i ahrolisomelioratsiya, 126. [In Ukrainian].

Kowalski, T., Bilanski, P., \& Holdenrieder, O. (2015). Virulence of Hymenoscyphus albidus and $H$. fraxineus on Fraxinus excelsior and $F$. pennsylvanica. Plos One, 10(10), 1-15.

Krakovska, S., Buksha, I., \& Shvidenko, A. (2017). Climate change scenarios for an assessment of vulnerability of forests in Ukraine in the 21st century. Aerul si Apa. Componente ale Mediului, 387-394.

Lakyda, P. I., \& Moroziuk, O. V. (2011). Cherkasy region forests: bioproductivity and dynamics. Korsun-Shevchenkivskyi, 222 p. [In Ukrainian].

Langer, G. (2017). Collar rots in forests of Northwest Germany affected by ash dieback. Baltic Forestry, 23, 4-19.

Lavnyy, V. V. (2000). Features of the formation of ash plantations of the Western Forest-steppe of Ukraine. Candidate Dissertation for Agricultural Sciences (06.03.03 - Silvics and Forestry), 176 p. [In Ukrainian].

Lockwood, B. R., \& LeBlanc, D. C. (2017). Radial growth-climate relationships of white ash (Fraxinus americana L. Oleaceae) in the eastern United States. The Journal of the Torrey Botanical Society, 144(3), 267-279.

Matsiakh, I. P., \& Kramarets, V. O. (2014). Declining of Common Ash (Fraxinus excelsior L.) in Western Ukraine. Scientific Herald of National Forest Technical University of Ukraine, 24(7), 67-74. [In Ukrainian].

Meshkova, V. L., \& Borysova, V. L. (2017). Damage causes of European ash in the permanent sampling plots in Kharkiv region. Forestry and Forest Melioration, 131, 179-186.

Pogrebnyak, P. S. (1955). Basics of forest typology. Kyiv: Academy of Sciences of the USSR. [In Russian].

Ray, D., Morison, J, \& Broadmeadow, M. (2010) Climate change: Impacts and adaptation in England's woodlands. Forestry Commission Research Note. Forest research, 2(1), 1-16.

I. M. Koval1, V. L. Borysova ${ }^{2}$

${ }^{I}$ Ukrainian Research Institute Forestry And Agromelioration named after H. M. Vysotskiy, Kharkiv, Ukraine ${ }^{2}$ Kharkiv National Agrarian University named after V. V. Dokuchaev, Kharkiv, Ukraine

\section{ASH RADIAL GROWTH RESPONSE TO CLIMATE CHANGE} IN THE STANDS OF LEFT BANK FOREST-STEPPE

Radial growth is an integral indicator reflecting the environmental impact on tree condition. Loss of forest resistance in the event of an unstable environmental situation may be reflected in the variability of radial growth of trees and its permanent depression. The purpose of the research was to study the response of Common ash (Fraxinus excelsior L.) radial growth to climate change in conditions of moist relative poor site conditions (subir). We used taxonomic, dendrochronological and statistical methods. Cores were taken by Pressler borer from 15 ash trees in a biogroup at a height of $1.3 \mathrm{~m}$ from the ground level in moist relative poor site conditions. We have studied the dynamics of the layer width of the early, late and annual wood of Fraxinus excelsior L. and the radial growth response on climate variations. The years of minimum growth $(1975,1987,1999,2000$, and 2012) have been established due to droughts, cold and warm winters, and abnormal early spring temperatures. Years of maximum growth $(1973,1980,1996$, and 2004) are 
characterized by a favourable ratio of heat and moisture. We have revealed differentiation among the trees of various categories of health condition through radial growth was caused by droughts during growing season in 1999-2000. The coefficient of sensitivity of the tree ring chronology of the late wood exceeds 0.3 , which indicates the strongest climatic signal in this chronology. Correlation was proved between widths of layers of early, late and annual wood from one side and climatic factors from another side. During 1975-1995, the ash radial growth was limited by high temperatures of the growing season, and in the following 1995-2016, the March, April and winter temperatures negatively influenced on the radial growth. The precipitation of September and December of the previous year positively influenced the ash radial growth in 1975-1995. For 1996-2016 we have detected negative influence of July precipitation on tree ring width. The number of significant relationships between climatic factors and tree ring widths did not increase in the second period, which indicates a sustained state of the forest stand.

Keywords: Fraxinus excelsior L.; late wood; early wood; annual wood; dendrochronological methods; climatic factors. 